\title{
Sobór Jerozolimski jako nastẹpstwo sporu apostolskiego w Antiochii (Dz 15,1-35)
}

Już u zarania Kościoła zrodziła się jedna z najpoważniejszych kwestii spornych w dziejach chrześcijaństwa: przyjęcie do wspólnoty wierzących w Chrystusa nawróconych z pogaństwa. Problem ten zrodził się prawdopodobnie w gminie antiocheńskiej, gdzie szczególnym charyzmatem misyjnym odznaczał się św. Paweł i Barnaba (Ga 2,1-10). Paweł jako dawny faryzeusz i skrupulatny obrońca dawnego prawa doskonale wiedział, jak wielkim ciężarem jest respektowanie skostniałych często przepisów Tory, które przedkładały literę nad ducha. Wiedział, że ich aplikowanie tym, którzy nigdy nie zetknęli się z tradycją Tory, nie doprowadzi ich do zbawienia, a raczej do formalizmu i powierzchowności w wierze. Dotyczyło to zwłaszcza problemu obrzezania, które, aplikowane poganom, od początku wydawało się św. Pawłowi bezcelowe (Ga 2,2-5). Spór o respektowanie dawnych przepisów bądź ich nie respektowanie nabrzmiał jeszcze wyraźniej w kontekście nieszczerej postawy św. Piotra w czasie jego misyjnej działalności, gdy inaczej traktował nawracających się na chrześcijaństwo Hebrajczyków, a inaczej pogan (Ga 2,11-21).

Sobór w Jerozolimie (Dz 15,1-35) podjął próbę rozwiązania tego problemu. Wypowiedział się on nie tylko pozytywnie na korzyść pogan w kwestii obrzezania, ale opracował także cztery podstawowe zasady życia pogan w pierwszych latach istnienia Kościoła. Celem niniejszego opracowania będzie zatrzymanie się nad problematyką teologiczną najważniejszego tekstu w Księdze Dziejów Apostolskich, ukazanie jego przemyślanej struktury i omówienie w każdej sekcji literackiej tekstu ${ }^{1}$ podstawowych problemów egzegetycznych.

\footnotetext{
${ }^{1}$ Trafnie stwierdza w swoim komentarzu do Dziejów Apostolskich B. Witherington (The Acts of the Apostels: A Social Rhetorical Commentary, Grand Rapids 1998, 439): „It is no exaggeration to say that Acts 15 is the most crucial chapter in the whole book".
} 


\section{Uwagi wstẹpne}

\subsection{Kontekst}

Dzieje Apostolskie zawierają opis jednego z najważniejszych wydarzeń w życiu Kościoła w pierwszych latach po zmartwychwstaniu i pięćdziesiątnicy: sprawozdanie ze zjazdu apostolskiego zwanego Pierwszym Soborem w Jerozolimie. Św. Łukasz przygotował opis tego wydarzenia w Dziejach Apostolskich na dwa sposoby: z jednej strony przez opis dzieła misyjnego św. Piotra, z drugiej - przez relacje o działalności misjonarskiej św. Pawła i św. Barnaby wśród pogan. Składają się na to następujące wydarzenia:

- dzieło misyjne św. Piotra (Dz 10,1-11,18):

a) chrzest Korneliusza (Dz 10),

b) przemówienie św. Piotra w Jerozolimie (Dz 11,1-17),

c) zgoda ze strony wspólnoty (Dz 11,18);

- dzieło misyjne św. Pawła i św. Barnaby:

a) misja wśród pogan $(13,1-14,26)$,

b) sprawozdanie z pobytu w Antiochii (14,25-27).

Po powiadaniu na temat Soboru Jerozolimskiego (Dz 15,1-35) następuje w Dziejach Apostolskich sekcja o przygotowaniach św. Pawła do tzw. drugiej podróży misyjnej (Dz 15,36-40). Z analizy i struktury całości Dziejów Apostolskich wynika, że ten krótki fragment nie należy już do narracji omawiającej wydarzenia związane z Soborem ${ }^{2}$.

\subsection{Struktura}

Struktura Łukaszowego tekstu o zjeździe apostolskim w Jerozolimie była często niewłaściwie określana ze względu na przesadne zainteresowanie egzegetów tego fragmentu Dziejów Apostolskich aspektami historycznymi. Jak możemy zauważyć, opis Dz 15,1-35 posiada strukturę bardzo logiczną

\footnotetext{
${ }^{2}$ Por.: A. Wikenhauser, Die Apostelgeschichte (RNT 5), Regensburg 1961, 182; G. Stählin, Die Apostelgeschichte (NTD 5), Göttingen 1962, 199.
} 
i jasną i nie przez przypadek znajduje się w centrum literackim i teologicznym całych Dziejów Apostolskich (jest to rozdział 15 w całości składającej się z 28 rozdziałów) ${ }^{3}$.

Informacje na temat czasu odbywania się Soboru nie należą do najważniejszych. Na pierwszy plan wybija się raczej uporządkowana sekwencja wydarzeń dotycząca konfliktów między apostołami co do głoszenia ewangelii, zwłaszcza wśród pogan, zakończona szczęśliwym rozwiązaniem problemu. W tym kontekście św. Łukasz powraca do faktów opisanych wcześniej, aby zademonstrować, w jaki sposób rozwiązanie sporu między apostołami zostało przygotowane w Bożym planie zbawienia, częściowo już dokonanym (Dz 15,7): Wiecie, bracia, że Bóg już dawno wybrat mnie spośród was. W wersecie 15,33 św. Łukasz zawiesza akcję, po tym jak apostołowie znaleźli rozwiązanie dla postawionych problemów i ogłosili rezultaty obrad soborowych ${ }^{4}$.

Dane dotyczące miejsca akcji wydają się istotniejsze dla zrozumienia całości fragmentu Dz 15,1-35. Łukasz rozpoczyna opis zjazdu apostolskiego w Syrii, w Antiochii i, poprzez pośrednie stacje: Fenicję i Samarię, przenosi ją do głównego miejsca wydarzeń: Jerozolimy. Następnie zmienia kierunek akcji i osadza ją ponownie w Antiochii. Jak widać, informacje na temat miejsca akcji tworzą swego rodzaju ramy narracji: Dz 15,1-4 - droga z Antiochii do świętego miasta Jeruzalem i 22-35 - wyjście ze świętego miasta Jeruzalem i powrót do Antiochii. Warto zaznaczyć, że w Dz 15,23 św. Łukasz wymienia krainy Syrii i Cylicji jako regiony znajdujące się pod wpływem Antiochii (w sensie pierwotnej administracji kościelnej).

Całość opisu dotyczącego Soboru Jerozolimskiego uzupełniają wyczerpujące informacje na temat osób związanych z tym wydarzeniem. We wskazanych już ramach opowiadania Dz 15,1-4 i 22-35 pojawiają się Paweł i Barnaba jako posłańcy do Jerozolimy. Dodatkowo w Dz 15,22-35 św. Łukasz wspomina Judę zwanego Barsabą i Sylasa. Do postaci wymienionych we fragmentach zwanych ramami opowiadania należy dodać również tzw. niektórych (Dz 15,1), którzy w Dz 15,5 objawiają się jako faryzeusze. List apostolski wymienia jeszcze apostołów i starszych braci wspólnoty (Dz 15,23). W czasie samego Soboru pojawiają się autorytety apostolskie jako mówcy: Piotr (Dz 15,7-11), Paweł z Barnabą (Dz 15,12) i Jakub (Dz 15,13-21). W podejmowaniu wiążących decyzji soborowych obok apostołów pojawiają się także starsi (Dz 15,6.22) i, przynajmniej pod koniec zgromadzenia, tzw. wszyscy, względnie - cały

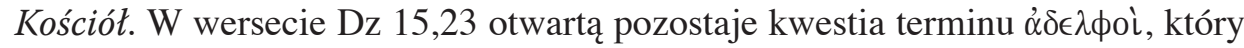

\footnotetext{
${ }^{3}$ Więcej na temat struktury Dz 15,35 por. F. F. Bruce, The Book of the Acts, Grand Rapids 1988, 285-300.

${ }^{4}$ Por. A. Wikenhauser, Die Apostelgeschichte, 171.
} 
może odnosić się do apostołów i starszych wymienianych we wcześniejszych wersetach lub, jak proponuje większość egzegetów, termin ten oznaczać może odrębną grupę. W każdym razie uczestnictwo innych członków Kościoła w obradach Soboru zostało podkreślone wyraźnie w Dz 15,12-22. Jeśli zauważymy, że Paweł wraz z Barnabą pojawiają się w tzw. ramach narracji (Dz 15,1-5 i 22-35) i odgrywają kluczową rolę podczas debaty soborowej (Dz 15,12), dochodzimy do struktury koncentrycznej całej sekcji. Fakt ten bardzo często bywa pomijany.

Znaki strukturalne potwierdzają dotychczasowe obserwacje. Wersety 15,1-5 (pierwsza część ram opowiadania) powiązane są ze sobą tematem obrzezania ( $\epsilon € \rho \iota \epsilon \in \mu \epsilon \iota \nu)$, natomiast imię Mojżesza zawarte w Dz 15,1-5 przygotowuje przejście do kolejnej, najważniejszej sekcji literackiej, do spotkania soborowego, które kończy się w Dz 15,21. Tu imię Mojżesza pojawia się ponownie. Kolejny fragment, czyli druga część tzw. ram opowiadania (Dz 15,22-35), zamykający sekcję o Soborze Jerozolimskim koncentruje się najpierw wokół

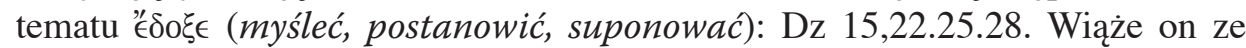
sobą przede wszystkim wersety 15,22-29. Fragment ten koncentruje się na redagowaniu dekretu apostolskiego. Tym samym wersety te łączą się tematycznie z obradami soborowymi i jednocześnie zapowiadają wydarzenia opisane w Dz 15,30-35, które podają skład delegacji udającej się do pogan z dekretem apostołów. Wpisują się one we wspomnianą Łukaszową koncepcję Antiochii, która jest punktem wyjścia całego opisu Soboru Jerozolimskiego i miejscem jego wypełnienia.

Warto wspomnieć również o informacjach św. Łukasza o ruchu kolejnych bohaterów w omawianym przez nas tekście:

- przybycie ludzi pochodzących z Jerozolimy do Antiochii (Dz 15,1),

- misja św. Pawła i św. Barnaby wraz z innymi w Jerozolimie (Dz 15,2-4),

- misja św. Pawła i św. Barnaby wraz z innymi w Antiochii (Dz 15,22-32),

- powrót Judy i Sylasa do Jerozolimy (Dz 15,33 - choć św. Łukasz nie wspomina ich imiennie).

Można zatem zauważyć, że mamy tu do czynienia z ruchem w przeciwną stronę: dwa razy z peryferii do centrum i dwa razy z centrum (z Jerozolimy) na peryferie (tzn. do Antiochii). Potwierdza to ponownie strukturę koncentryczną całego opowiadania o Soborze Jerozolimskim w Dz 15,1-35.

\subsection{Jedność literacka narracji Dz 15,1-35; źródta lub tradycje}

Pytania o źródła czy tradycje dotyczące narracji o Soborze Jerozolimskim wynikają bardziej z ciekawości historycznej aniżeli z samego tekstu, jaki mamy 
do dyspozycji dzisiaj. Chociażby z punktu widzenia stylu, tekst jest tak bardzo jednolity, że stawianie hipotezy o źródła i tradycje wydaje się bezzasadne. Mimo to pytania o źródła w odniesieniu do narracji Dz 15,1-35 stawiane były od bardzo dawna. Ich podstawą są zbieżności i różnice, jakie zachodzą pomiędzy tekstem o Soborze Jerozolimskim w Dz 15,1-35 a tzw. „Incydentem Antiocheńskim” w Ga 2. Poszukiwania zmierzające do ustalenia ewentualnych podobieństw i różnic w tym materiale biblijnym bazują zasadniczo na źródłach wykorzystanych przez św. Łukasza w Dziejach Apostolskich, nie pochodzą natomiast od św. Pawła.

- hipoteza jednego źródła

Według tej teorii, cała sekcja Dz 15,1-35 należy do tzw. źródła antiocheńskiego wraz z tekstem Dz 12,25-14,28. Opinię tę wysunął A. von Harnack. Koncepcja ta napotyka na trudności, bowiem interwencja św. Piotra (Dz 15,7-11) wspomina również rozmowę z Korneliuszem, która w żaden sposób nie przystaje do tego źródła. Druga koncepcja pochodzi od B. Weissa, który stwierdza, że z jednego źródła pochodzą mowy św. Piotra i św. Jakuba. Materiał ten zawiera jednak drobne korekty św. Łukasza, które pochodzą z innych źródeł5.

Według ostatnich badań, zarówno dyskurs św. Jakuba, jak i sam dekret apostolski (Dz 15,13-21.22-29) pochodzą z jednego źródła. Świadczy o tym choćby powtórzenie słów dekretu w wersecie 12,29. Jednakże to powtórzenie mogło być dziełem samego Łukasza. Warto zaznaczyć jeszcze, że, według M. Dibeliusa, tylko dekret soborowy pochodziłby z jednego źródła, natomiast pozostały materiał w rozdziale Dz 15,1-35 wyszedł spod ręki św. Łukasza 6 .

- hipoteza dwóch źródet

Zwolennikiem tej teorii był R. Pesch. Według niego, Łukasz wykorzystał dwa źródła: jedno z nich opisuje ugodę osiągniętą w Jerozolimie między Pawłem i Piotrem wraz z jego stronnictwem, która dotyczyła dopuszczenia pogan do

${ }^{5}$ Por. B. Weiss, Die Apostelgeschichte: Textkritische Untersuchungen und Textherstellung (TU 9.3/4), Leipzig 1893, 233.

${ }^{6}$ Por. M. Dibelius, The Apostolic Council, w: Studies in the Acts of the Apostels, red. H. Greeven, London 1955, 98-99. 
sakramentu chrztu św. bez poddawania ich uprzedniemu obrzezaniu. (Ga 2,110 = Dz 15,1-4.12b); drugie źródło opisywałoby konflikt antiocheński między wyżej wymienionymi apostołami co do powszechnego powołania pogan (Ga 2,11-14 = Dz 15,5-12a.13-33) .

- hipoteza tzw. ..jednej tradycji”

E. Haenchen wysunął teorię, w której sugerował, iż Łukasz skomponował tekst o soborze jerozolimskim w sposób mniej lub bardziej niezależny, dokonując tylko nielicznych odniesień i aluzji tylko do jednego źródła - „,dekretu apostolskiego", który kryje się za opisem w Dz 15,20-29. Jednak ta bardzo radykalna teoria jest w dzisiejszej egzegezie powszechnie zarzucona. Bardziej prawdopodobna wydaje się propozycja, według której św. Łukasz w opisie wydarzeń zawartych w Dz 15 opierał się na tradycji paralelnej do tekstu Ga 2,1-10.11-14 (konflikt antiocheński i porozumienie jerozolimskie) i swój własny tekst zintegrował ze swoim własnym tekstem. Za taką hipotezą opowiadają się m.in. H. Conzelamann i G. Schneider ${ }^{8}$.

Możliwe również, że informacje św. Łukasza konieczne do napisania opowiadania o Soborze Jerozolimskim należy zredukować do jednej tradycji, tzn. do Listu do Galatów. Prawdopodobnie zestawił on ze sobą, w dowolny sposób, dwa opisane tam wydarzenia.

\section{Sobór Jerozolimski}

\section{- okoliczności, przygotowania i otwarcie (Dz 15,1-12)}

\subsection{Okoliczności i przygotowanie Soboru Jerozolimskiego (Dz 15,1-5)}

\subsubsection{Struktura}

Z punktu widzenia semantycznego możemy wyróżnić inkluzję w werse-

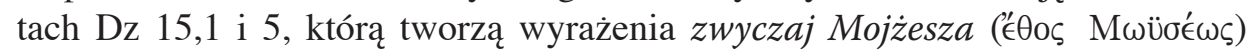

\footnotetext{
${ }^{7}$ Por. R. Pesch, Die Apostelgeschichte (EKKNT), t. 1-2; Neukirchen - Vluyn 1986, 78-79.

${ }^{8}$ Por. E. Haenchen, Die Apostelgeschichte, Göttingen 1956, 227-228; H. Conzelmann, Die Apostelgeschichte (HNT 7), Tübingen 1963, 87-88; G. Schneider, Die Apostelgeschichte (TKNT 5), t. 2, Freiburg - Basel - Wien 1982, 179-181.
} 


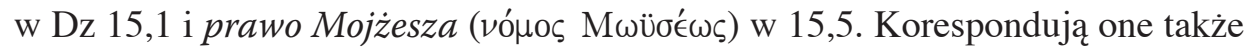
z wersetem Dz 15,21, gdzie św. Łukasz jeszcze raz wzmiankuje o tych, którzy

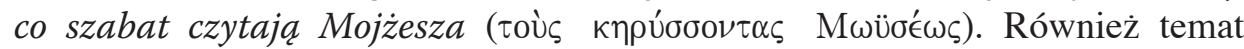
obrzezania należy do tzw. ram opowiadania. W ten sposób wersety Dz 15,1-5 z jednej strony tworzą jednolitą i tematyczną całość, z drugiej zaś łączą się one dobrze z bezpośrednim kontekstem w Dz 15,21. Warto zauważyć również, że wraz $z$ wersetem 15,5 rozpoczyna się w naszej narracji nowy wątek i wraz z wersetem 15,21 tworzy ramy nowej sekcji wewnątrz opowiadania o soborze jerozolimskim. $Z$ powyższych informacji wynika, że werset 15,5 służy więc za pomost lub przejście, prowadząc akcję w opowiadaniu o Soborze Jerozolimskim od podania powodów jego zwołania, aż do opisu jego przygotowań9.

Z punktu widzenia syntaksy zwraca uwagę zmiana podmiotu opowiadania w wersetach Dz 15,1-4 i 15,5. Na początku narracji św. Łukasz wzmiankuje niektórych (Dz 15,1), następnie w Dz 15,2 inicjatywa przechodzi na braci, wspominanych także w Dz 15,1. Wypada zaznaczyć, że chodzi tu o członków wspólnoty. Wersety 15,3-4 charakteryzują się aktywnością i przeznaczeniem posłańców wspólnoty: Pawła, Barnaby i ich towarzyszy. Natomiast informacja o niektórych w Dz 15,5 kończy jedną sekcję i otwiera nową.

\subsubsection{Redakcja Dz 15,1-5}

Święty Łukasz jest prawdopodobnie twórcą połączenia tematycznego pomiędzy tzw. „,konfliktem antiocheńskim” i ,ugodą jerozolimską”. Potwierdza to werset Dz 15,1. Język, jakim operuje ewangelista w tym tekście, mówi o niektórych $\left(\tau \iota \nu \in \varsigma_{)}\right)$. Termin ten jest bardzo szeroki. W Liście do Galatów mowa jest również o $\tau \iota \nu \in \varsigma$, którzy przybyli od Jakuba i oskarżali św. Piotra, że zaprzestał spożywania posiłków wspólnie z nawróconymi spośród pogan. Święty Jakub jako wysyłający delegację nie był użyteczny dla Łukasza, ponieważ widział on w nim mediatora, który nie chciał nakładać na nawróconych pogan nadmiernego ciężaru Tory. Tym samym święty Łukasz nie wspomina jerozolimskiego pochodzenia owych niektórych, mówi co najwyżej o tym, że przybyli z Judei.

W wersecie Dz 15,2 mowa jest o niematych sporach $i$ zatargach ( $\sigma \tau \alpha \dot{\sigma} \sigma \varsigma$

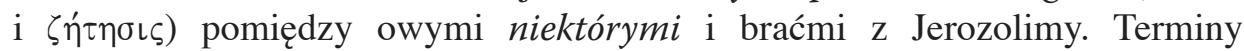

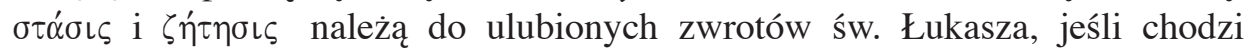
o przedstawianie sporów i kłótni (powtarza je także werset Dz 15,7 - по $\lambda \lambda \hat{\eta} \varsigma$ $\left.\delta^{\prime} \epsilon \zeta \eta \eta^{\prime} \sigma \epsilon \omega \varsigma\right)$. Emocje, jakie pojawiły się na początku Soboru Jerozolimskiego

\footnotetext{
${ }^{9}$ Por. F.F. Bruce, The Book of the Acts, Grand Rapids 1988, 288-289.
} 
wywołało zwłaszcza pojawienie się Pawła i Barnaby, jakkolwiek w drugiej części opisu soborowych obrad zostają oni włączeni do grona tych, którzy znajdują, razem z innymi, rozwiązanie sporu. Imiona Pawła i Barnaby oraz określenia apostołowie i starsi są wynikiem zachowanej dawnej tradycji o Soborze ${ }^{10}$.

Kolejnym elementem literackim, który przemawia za Łukaszową

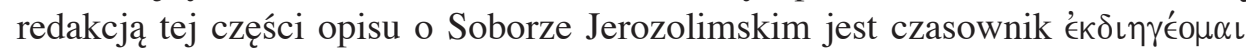
(opowiadać, relacjonować, czynić sprawozdanie) o doświadczeniu Bożej ingerencji w nawrócenie pogan. Podobna informacja znajduje się w tekście Dz 14,26. Wymienione przez autora nazwy geograficzne Fenicji, Samarii i Syrii wskazują na regiony poza Ziemią Świętą, czyli poza granicami judaizmu. Jest to Łukaszowe przygotowanie terytoriów, do których skierowane zostanie przyszłe przesłanie Soboru.

Werset Dz 15,4 opisuje, jak Paweł i Barnaba opowiedzieli w Jerozolimie o wielkich dziełach, których Bóg przez nich dokonał w Antiochii i okolicach. Zwrot: dzieła jakich Bóg dokonat przez nich koresponduje z wypowiedzią zawartą w Dz 14,27. Jest to kolejna wskazówka co do redakcyjnej pracy św. Łukasza w przygotowaniu tekstu $\mathrm{Dz}$ 15,1-5. W wersecie Dz 15,5 pojawia się wzmianka o pojawieniu się niektórych członków ze stronnictwa faryzeuszy. Ta informacja przygotowuje przejście do następnej sekcji oraz ukazuje, że najwięksi rygoryści w przestrzeganiu przepisów Tory nie współdziałali ze św. Jakubem Apostołem.

\subsection{Otwarcie Soboru Jerozolimskiego (Dz 15,6-12)}

\subsubsection{Zwołanie Soboru Jerozolimskiego - Dz 15,6}

Św. Łukasz sformułował swoje opowiadanie na temat zwołania Soboru w Jerozolimie w oparciu o model, jaki funkcjonował podczas zebrań Sanhedrynu. Schemat takiego zwołania podaje traktat Miszny na ten temat, oparty o tekst Pwt 17,8-13. Według tej hipotezy, decyzje, jakie zostały podjęte w Dz 15, należy uznać za doktrynalnie autorytatywne, analogicznie jak decyzje doktrynalne Sanhedrynu. Pewną trudność sprawia jednak terminologia użyta przez św. Łukasza, który mówi o wszystkich (Dz 15,12) i o braciach (członkach wspólnoty - Dz 15,23) jako o wspólnocie, tak iż nie możemy od razu uznać jej jako organu ustawodawczego i decydującego jednoznacznie w sprawach doktrynalnych.

\footnotetext{
${ }^{10}$ Por. A. Weiser, Die Apostelgeschichte, t. 1, Gütersloh 1980, 27.
} 


\subsubsection{Opowiadanie i propozycja św. Piotra (Dz 15,7-11)}

Jeżeli porównamy ze sobą dwa głosy soborowe - Piotra i Jakuba - to zauważamy, że pierwszy z nich daje solidne podstawy teologiczne, drugi rozwiązania praktyczne w oparciu o Pismo św. Wywód św. Piotra ma dwie wyraźne części: odwołanie się do tradycji i doświadczenie (Dz 15,7-9) oraz konsekwencje z tego wynikające $(15,10-11)^{11}$. Słownictwo i styl interwencji św. Piotra zdradzają rękę św. Łukasza. Można zauważyć w nim także wpływ LXX oraz św. Pawła i jego szkoły.

- Tradycja i doświadczenie (Dz 15,7-9): św. Piotr opowiada o tym, co przeżył już dawno temu, przy okazji nawrócenia setnika Korneliusza i jego domu (Dz 10,1-18). Był to, według niego, wybór samego Boga (Dz 15,7). Doświadczenie dotyczyło daru Ducha św. dla Korneliusza (Dz 15,8). Wzmianka o oczyszczeniu ich serc przygotowuje następny fragment tekstu.

- Konsekwencje (Dz 15,10-11): przekonanie, że przepisy Prawa są ciężarem nie do udźwignięcia, nie jest doświadczeniem teologii judaistycznej, ani też Pawłowej, lecz przekonaniem chrześcijaństwa czasów św. Łukasza ${ }^{12}$. „Usprawiedliwienie z wiary” jest wyrażeniem typowym dla soteriologii św. Pawła: Rz 3,21-23; Ga 2,15-21. Św. Łukasz wkłada tę myśl w usta św. Pawła podczas jego dyskursu w Antiochii Pizydyjskiej (Dz 13,38-39). W Dz 15 ten sam argument podnosi św. Piotr, chociaż forma literacka tego wyrażenia, jak potwierdza Dz 15,10, może ulegać zmianom: „usprawiedliwienie/zbawienie przez wiarę/łaskę" (św. Paweł wypowiada się na temat usprawiedliwienia z wiary w Ga 2,21, a jego szkoła - Ef 2,8, natomiast temat zbawienia przez łaskę Chrystusa św. Paweł podejmuje w Rz 5,15 i 2 Kor 8,9, a jego szkoła w 1 Tm $1,14)$.

\subsubsection{Rola św. Pawta i św. Barnaby (Dz 15,12)}

Milczenie, jakie zapadło po wypowiedzi św. Piotra, jest odpowiedzią na kontrowersję, jaka powstała na początku obrad soborowych (Dz 15,7), i ukazuje efekt, jaki wywołały słowa pierwszego apostoła. Paweł i Barnaba również odwołują się do doświadczenia, które było ich udziałem podczas Pierwszej Podróży Misyjnej. Warto zauważyć, że w Dz 15,10 św. Barnaba

\footnotetext{
${ }^{11}$ Por. H. Conzelmann, Die Apostelgeschichte, 90.

${ }^{12}$ Por. H. Van de Sandt, An Explantation of Acts 15,6.21 in the Light of Deuteronomy 4.29-35 (LXX), JSNT 46 (1992) 73.
} 
jest wymieniany przed św. Pawłem. Św. Łukasz przedstawia misjonarzy w ten sposób prawdopodobnie ze względu na fakt, iż św. Barnaba był lepiej znany w gminie jerozolimskiej i to on wprowadził św. Pawła do wspólnoty pierwotnego Kościoła (Dz 9,27). Boże dzieło między poganami ukazuje się podczas pierwszej podróży misyjnej w znakach i cudach, które Pan uczynił przez ręce apostołów. Przykładem tego działania jest utrata wzroku przez Elimasa na Cyprze (Dz 13,8-11), uzdrowienie chromego kaleki w Listrze (Dz 14,8-10), ale także cudowne znaki, które św. Łukasz wspomina przy okazji pobytu św. Pawła i św. Barnaby w Listrze (Dz 14,3). Dla Łukasza znaki te są wyrażeniem i potwierdzeniem Bożego wybrania pogan, z którego wspólnota jerozolimska winna wyciągnąć konsekwencje.

\section{Sobór Jerozolimski: wywód św. Jakuba i rozwiązanie konfliktu (Dz 15,13-29)}

Wydaje się, że wypowiedzi św. Piotra i św. Pawła, a także św. Barnaby zostały oddzielone od dyskursu św. Jakuba (brata Pańskiego) tylko ze względów praktycznych. Zarówno względy formalne, jak i kontekst wskazują jednak, że wszystkie trzy opisy są ze sobą ściśle powiązane. Razem tworzą one jednolitą i zwartą całość. Sygnałem ukazującym ową jedność jest wspomniane imię Mojżesza, które razem z terminem prawo tworzy wyraźną inkluzję całej sekcji (Dz 15,1 i 15,21). Drugi element literacki, który możemy traktować jako temat-klucz w naszej sekcji to obrzezanie. Odnajdujemy go w wersetach Dz 15,1.6. Ostatnia ciekawa inkluzja znajduje się w wersetach Dz 15,7: od dawna;

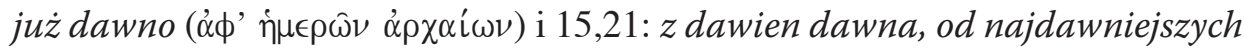


15,7-21 tworzą jedność literacką.

W wersecie Dz 15,22 rozpoczyna nową jednostkę literacką. Inkluzją

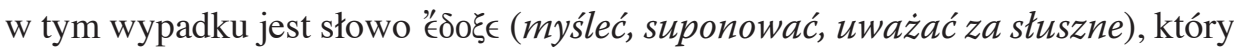
został powtórzony w wersetach Dz 15,25.28 i przez to wskazuje na początek, centrum i zakończenie całej sekcji. Jeśli chodzi o materiał zebrany w tej sekcji, to zawiera on opis dyskusji, rozwiązanie problemu ze strony wspólnoty i wypełnienie postanowień wraz z opisem redakcji listu, który zostanie wysłany do wspólnoty w Antiochii. 


\subsection{Wypowiedź św. Jakuba (Dz 15,13-21)}

Po wprowadzeniu do wypowiedzi (Dz 15,13a) możemy wyróżnić w nim pięć części: prośbę o uwagę słuchaczy $(15,13 \mathrm{~b})$; nawiązanie do wypowiedzi św. Piotra $(15,14)$; świadectwo oparte na słowach proroka $(15,15-18)$; ostateczny wniosek zredagowany na bazie wypowiedzi prorockiej $(15,19-20)$; uzasadnienie zredagowanej konkluzji $(15,21)$.

- wprowadzenie do wypowiedzi (15,13a)

Milczenie, o którym mowa na początku tej sekcji, jest przedłużeniem wspomnianego już milczenia w Dz 15,12, które wywołała wypowiedź św. Pawła i św. Barnaby. Werset Dz 15,13a akcentuje więc moment cichej refleksji, po której następuje wypowiedź św. Jakuba, brata Pańskiego, wspomnianego już w Dz 12,27. Należy go odróżnić od św. Jakuba, syna Zebedeusza, o którym św. Łukasz mówi w Dz 12,2 w kontekście jego śmierci. Był on, według tradycji Pawłowej, jednym z filarów pierwotnego Kościoła.

- prośba o uwage stuchaczy $(15,13 b)$

Podobna prośba znajduje się w także w innych wypowiedziach misyjnych opisanych w Dziejach Apostolskich. Wystarczy wspomnieć tu o dyskursie św. Piotra w dniu Pięćdziesiątnicy (Dz 2,14a). Wspomnienie braci w kontekście Dz 15,13 b wydaje się schematyczne i pozwala rozstrzygnąć, czy podczas obrad soboru obecne były także kobiety (ich działalność wspomina św. Łukasz już w pierwszych dniach działowości pierwotnego Kościoła - Dz 1,14).

- nawiązanie do wypowiedzi św. Piotra (Dz 15,14)

Św. Jakub nawiązuje do słów św. Piotra, używając jednak dawnego imienia Szymon. Takie użycie dawnego imienia pierwszego apostoła jest prawdopodobnie świadomą archaizacją zastosowaną przez św. Łukasza dla zaakcentowania faktu, iż św. Jakub - judeochrześcijanin - adresuje swoje słowa przede wszystkim do św. Piotra także judeochrześcijanina, używając terminów zaczerpniętych 
z ojczystego języka ${ }^{13}$. Z wypowiedzi św. Jakuba wynika, że Bóg wybrał sobie spośród różnych narodów pogańskich ( $(€ \vee \omega \omega \nu)$ jeden lud $\left(\lambda \alpha \varsigma_{\varsigma}\right)^{14}$. Wydaje się, że mamy tu do czynienia z zamierzoną grą słów, która ma zilustrować jednej strony ideę wybrania Izraela, z drugiej zaś jego pokrewieństwo z sąsiednimi narodami. Ostatnia myśl zostanie rozwiniętą w kolejnych rozdziałach, gdy św. Łukasz podejmie temat rozszerzenia daru zbawienia na wszystkie narody (II i III podróż misyjna św. Pawła).

- świadectwo oparte na słowach proroka $(15,15-18)$

Według słów św. Jakuba, powołanie pogan potwierdzają przede wszystkim Księgi Dwunastu Proroków Mniejszych, do których należy również dzieło proroka Amosa. Od niego pochodzi, w wersji wyjętej z LXX, cytat Am 9,11-12. W tekście Dz 15,16-17 możemy dostrzec także wpływ innych dwóch tekstów: Jr 12,15 i Iz 45,21. Nawet jeśli Łukasz w tekście wyjętym z Księgi Proroka Amosa oparł się zasadniczo na tłumaczeniu LXX, nie jest wykluczone, że jego pierwotna wersja opierała się na tekście hebrajskim, nieco tylko zmienionym od znanej nam dzisiaj wersji $\mathrm{TM}$ w $\mathrm{BH}^{15}$. Istotne znaczenie ma przede wszystkim niewielka zmiana między hebrajskim terminem jdrsw'l (szukać, konsultować, martwić się, odptacić) zamiast jjrsw't (wziać w posiadanie, posiaść). Tekst Am 9,11 różny od tego, jaki notuje tekst TM w BH, znajdujemy w zwojach qumrańskich: CD 7,16 i w 4QMidrEschat 1,12. Użytą tam wersję czasownika jjrsw't tłumaczymy jako „on zrekonstruuje”. Również wprowadzenie do 4QMidrEschat 1,12 zawiera podobne sformułowania jak wstęp do Dz 15,15: jak jest napisane; bo napisano. Można więc przypuszczać, że słowa, które rozpoczynają cytat wyjęty z Księgi Proroka Amosa pochodzą bezpośrednio od św. Łukasza. Chodzi tu zwłaszcza o sformułowanie: po czym powrócę. Tekst cytatu wspomina „namiot Dawida” (według Brauna - „namioty”) ${ }^{16}$, który odnosi się do domu królewskiego. Ta wzmianka może sugerować pochodzenie tekstu z czasów wygnania babilońskiego i jest dodatkiem do tekstu proroka Amosa,

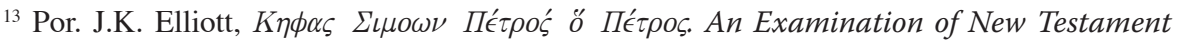
Usage, NovT 14 (1972) 248.

${ }^{14}$ Por. F.F. Bruce, The Book of the Acts, 293.

${ }^{15}$ Por. M. Braun, James' Use of Amos at the Jerusalem Council: Steps Toward a Possible Solution of the Textual and Theological Problems, JETS 20 (1977) 113-114; H. Van de Sandt, An Explantation of Acts 15,6.21 in the Light of Deuteronomy 4.29-35 (LXX), 77.

${ }^{16}$ Por. W. Kaiser, The Davidic Promise and the Inclusion of the Gentiles (Amos 9,9-15 and Acts 15,13-18): A Test Passage for Theological Systems, JETS 20 (1977) 97-98. 
który żył w VIII wieku przed Chr. Wydaje się również, że św. Łukasz odnosi ów cytat do odnowy i rekonstrukcji całego Izraela. Inni ludzie (Dz 15,17) jest wersją tekstu Amosa możliwą do przyjęcia (termin adam zamiast Edom, nie zmieniając samogłosek). Prorokowi chodziło jednak raczej o Izraela jako naród, bez uwzględniania innych ludów, ponieważ idea tzw. „reszty”, w sensie pozytywnym, jest zarezerwowana w ST do narodu wybranego. Wyrażenie wszystkie narody (Dz 15,17), jest raczej dodatkiem aniżeli wyjaśnieniem. Tak więc, w czasach ostatecznych, zarówno Izrael, jak narody pogańskie (jako takie), poznają Boga. To jest punkt decydujący w argumentacji. Bóg od wieków przez proroka objawił swoją wolę powszechnego zbawienia, którą teraz realizuje (Dz $15,18)$.

- ostateczny wniosek zredagowany na bazie wypowiedzi prorockiej $(15,19-20)$

Po słowie prorockim św. Łukasz umieszcza uwagę o tym, by nie obciążać $\left(\pi \alpha \rho \in \nu 0 \chi \lambda \lambda^{\prime} \omega\right)$ zbytnio wymaganiami nawracających się do Boga pogan (Dz $15,19)$. W tym punkcie, Łukasz prezentuje św. Jakuba w postawie zasadniczej zgody ze św. Piotrem (por. Dz 15,10), który ze swej strony myśli i argumentuje w sposób podobny do św. Pawła. Cztery zasady soborowe zawarte w Dz 15,20 wydają się zaczerpnięte z tekstów starotestamentalnych: Kpł 17,8-16 i 18,6-18. ${ }^{17}$ W Księdze Kapłańskiej 17 cztery zasady oznaczają przepisy, które musi respektować także każdy obcy mieszkający pośród Izraela (Kpł 17,10). Wynika z nich również, że nierząd ( małżeństw nielegalnych pomiędzy bliskim krewnymi (por. Mt 5,32; 19,9). Niektóre kodeksy w miejsce zasady mówiącej o powstrzymaniu się od „tego co uduszone” umieszczają tzw. „złotą zasadę” (Mt 7,12), ograniczając tradycyjny spis zasad soborowych do trzech: „krew”, która odnosi się do unikania zabójstwa; „ofiary dla bożków”, a więc powstrzymywanie się od apostazji oraz „nierząd”, czyli unikanie grzechów związanych z cudzołóstwem. Tym samym docieramy do podstawowego zestawienia głównych grzechów, jaki obowiązywał w pierwotnym Kościele. Wydaje się jednak, że zestawienie głównych grzechów, które pojawia się w późniejszych kodeksach, zwłaszcza w Kościele Zachodnim, ukazuje późniejsze stadium tradycji biblijnych. ${ }^{18}$

${ }^{17}$ Por T. Callan, The Background of the Apostolic Decree (Acts 15,20.29; 21,25), CBQ 55 (1992) 285-290.

${ }^{18}$ Por. F.F. Bruce, The Book of the Acts, 296. 
- uzasadnienie zredagowanej konkluzji $(15,21)$

Jeżeli odniesiemy cztery zasady soborowe w Dz 15,20 do Kpł 17, to uzasadnienie decyzji ojców Soboru wzmiankowane w 15,21 nabiera sensu: Mojżesz, a ściśle mówiąc - przepisy Tory, były czytane od najdawniejszych czasów podczas liturgii szabatowej w synagogach, także ich treść, jak można suponować, była znana prawie w każdym zakątku ówczesnego świata. Należy zauważyć, że zachowanie czterech zasad podanych przez św. Jakuba nie jest ukazane jako konieczne do zbawienia, lecz jedynie moralnie wiążące i pożyteczne. Tym samym Prawo jako droga do zbawienia nie zostało podtrzymane. ${ }^{19}$

\subsection{Dekret apostolski i jego wykonawcy (Dz 15,22-29)}

Z wcześniejszych obserwacji wynika, że przy wykonaniu dekretu mamy do czynienia $\mathrm{z}$ ruchem odwrotnym stosunku do tego, jaki zaznaczył św. Łukasz w momencie zwołania Soboru: Paweł i Barnaba wraz kilkoma towarzyszami wyruszają z Antiochii do Jerozolimy, aby znaleźć rozwiązanie dla palących problemów antiocheńskiej gminy (Dz 15,1-4). Po ogłoszeniu dekretu i znalezieniu rozwiązań dla nawracających się spośród pogan, misjonarze wracają do Antiochii. Towarzysze tej podróży są jednak nowi: Juda Barsabas pojawia się tylko w tym fragmencie Dziejów (w Dz 1,21 spotykamy Justusa Barnabę, który być może był jego krewnym) oraz Sylasa, którego należy utożsamiać ze Sylwanem, o którym pisze św. Paweł (2 Kor 1,19; 1 Tes 1,1; 2 Tes 1,1) i św. Piotr w 1 P 5,12. Jeśli chodzi o wysyłających, to oprócz apostołów i starszych, należy wspomnieć również „całą wspólnotę”, „cały Kościół” jako autorów listu.

Struktura lista apostolskiego zawiera zasadnicze elementy charakterystyczne dla innych listów antycznych: wstęp i pozdrowienie $(15,23)$; zasadniczy korpus listu (Dz 15,24-29b) oraz pozdrowienie końcowe ze starożytną formułą: " $\rho \rho \omega \sigma \theta \epsilon$ (badźcie zdrowi) potwierdzoną w NT tylko w tym tekście Łukaszowym (Dz 15,29c). Wstęp wymienia wysyłających: apostołów i braci ( $\dot{\delta} \in \lambda \phi o i)$ oraz adresatów, pośród których obok Antiochii wymieniane są Kościoły w Syrii i Cylicji, tzn. ojczyzna św. Pawła.

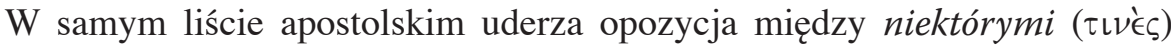
w Dz 15,24, a drugiej strony obecność całej wspólnoty zgromadzonej w jednym

${ }^{19}$ Por. W. Radl, Das Gesetz in Apg 15, w: Das Gesetz im Neuen Testament (QD 108), red. K. Kertelge, Freiburg/B. 1986, 169-174. 
duchu (Dz 15,25), którą stoi sam Duch Święty (Dz 15,28). Tak więc to, co do tej pory było tylko opinią Pawła, Barnaby i Jakuba - nie nakładać nadmiernych ciężarów na nawróconych spośród pogan - staje się teraz decyzją wiążącą całą wspólnotę, która ma obowiązywać również od tej chwili także diasporę. Tekst listu powtarza jeszcze raz cztery zasady soborowe, które jednak nie są warunkami koniecznymi do zbawienia. Mowa jest tylko o tym, że nawracający dobrze zrobią zachowując je lub inaczej interpretując: zasady te przyczynią im dobra, jeśli zostaną przez nich zachowane.

Można zatem stwierdzić, że wraz z wysłaniem listu rozwiązany zostaje fundamentalny problem włączenia pogan do wspólnoty Kościoła. Uderza fakt nie podejmowania dyskusji na temat obrzezania. Nie oznacza to, że wszystkie problemy związane ze współżyciem judeochrześcijan i nawróconych z pogaństwa, zwane „konfliktem antiocheńskim” zostały załatwione. Już sam list wskazuje, że pewne trudności pozostały choćby dlatego, że wśród czterech zasad aż trzy dotyczą spożywania pokarmów, czyli jednej z najbardziej spornych kwestii całej Tory. Kwestia małżeństw między spokrewnionymi nie wpisuje się $\mathrm{w}$ tę problematykę. Trzeba zauważyć, że trudności we wzajemnym współżycie nawróconych z pogaństwa i judeochrześcijan stoją w tle historii Piotra i Korneliusza, szczególnie zaś wizja Piotra w domu Szymona garbarza (Dz 10,6-16). ${ }^{20}$ Łukasz w swoim dziele mocna uwypukla problem wpływu judaizmu na zasady życia chrześcijańskiego i jest zwolennikiem ich ograniczenia, szczególnie wobec katechumenów pochodzących z pogaństwa. Otwiera on tym samym drogę dla misji, przede wszystkim św. Pawła, pośród pogan. To ona staje się jedynym tematem w pozostałych rozdziałach Dziejów Apostolskich.

\section{Promulgacja dekretu apostolskiego (Dz 15,30-35)}

\subsection{Tekst}

Jak zostało wspomniane, powrót Pawła i Barnaby do Antiochii tworzy inkluzję literacką i narracyjną wraz z opisem ich wyjazdu do Jerozolimy w Dz 15,1-5. Poza tym termin „Antiochia” stanowi centralny temat ostatniej sekcji literackiej w całej narracji na temat Soboru Jerozolimskiego (Dz 15,30-35). Z punktu widzenia syntaksy, odnajdujemy w tekście szereg czasowników

\footnotetext{
${ }^{20}$ Por. P.J. Achtemeier, An Elusive Unity: Paul, Acts, and the Early Church, CBQ 48 (1986) 6.
} 
i rzeczowników, które pozwalają wyróżnić emfazy Łukasza w każdym z wersetów tej sekcji. Z drugiej strony możemy zauważyć także częste zmiany podmiotu gramatycznego: w Dz 15,30 - czterej misjonarze-posłańcy ze wspólnoty jerozolimskiej; Dz 15,31 - członkowie wspólnoty chrześcijańskiej w Antiochii; Dz 15,32 - Juda Barsaba i Sylas; Dz 15,35 - Paweł i Barnaba. Mówiąc o czterech misjonarzach, Łukasz podkreśla ich powrót do Antiochii i przekazanie dekretu. Wersety opisujące wskazówki dla wspólnoty Łukasz komponuje w podobny sposób: otwiera je imiesłów, a w drugiej części wersetu stosuje formę osobową: Dz 15,30: zwoławszy - oddali; Dz 15,31: przeczytano - ucieszyli się. Wobec Judy Barsaby i Sylasa podkreślone jest najpierw ich przepowiadanie prorockie, a następnie ich zasługi dla wspólnoty. W ten sposób pojawia się ponownie komplementarność miedzy wskazówkami dotyczącymi wiary misjonarzy i ich wspólnoty (Dz 15,32). W przypadku Pawła i Barnaby, Łukasz podkreśla ich przedłużony pobyt w Antiochii (imperfectum), który służy jako pouczenie i sposobność do przepowiadania Ewangelii (Dz 15,35). Tym samym autor dotyka ponownie fundamentalnego tematu Dziejów Apostolskich.

\subsection{Teologia}

Św. Łukasz przekazuje obraz bardzo harmonijnego zakończenia soboru i jego wypełnienia. Podobny obraz kreślił już opisując przebieg soboru w Jerozolimie. Tam, gdzie nie ma do dyspozycji precyzyjnych wiadomości historycznych, tak jak odbywa się to w przypadku promulgacji postanowień soboru, czy też w przypadku Pawła i Barnaby podczas ich Pierwszej Podroży Misyjnej (por.: Dz 14,21-28 posiada elementy wspólne z Dz 15,30-35), Łukasz podkreśla elementy typowe dla formacji i umocnienia całej wspólnoty. Jako element centralny ukazuje on swobodne przepowiadanie Słowa Bożego, którego nie mogą ograniczyć czy zatrzymać ani prześladowania zewnętrzne, ani wewnętrzne konflikty we wspólnocie.

\subsection{Historia}

Z punktu widzenia historycznego, miejscem skomponowania Dekretu Apostolskiego byłaby raczej Antiochia aniżeli Jerozolima. Istnienie takiego dokumentu staje się prawdopodobne, gdy czytamy takie teksty, jak: Dz 2,14.20; 
Dialog św. Justyna 34,8; Tekst Miniciusa Felixa 30,621. Prawdopodobnie dekret ten był promulgowany po konflikcie Pawła z Piotrem i definitywnym wyjeździe tego pierwszego z Antiochii. Listy św. Pawła nigdzie nie potwierdzają znajomości podobnego dokumentu. Opis Łukasza harmonizuje relacje o dwóch różnych konfliktach między Pawłem, Jakubem, Piotrem i Barnabą za pomocą jednego opowiadania, które w Liście do Galatów różnią się chronologią i tematyką ${ }^{22}$. Omówienie poszczególnych postanowień dekretu możemy odnaleźć w niektórych fragmentach jego pism: Rz 14 - stosunek do idoli; Ga 2,12 - prawa i przepisy, które dotykają pokarmów. Również powrót Sylasa, względnie Sylwana z Antiochii do Jerozolimy, który ze względu na informację w Dz 15,40 jest niemożliwy, potwierdzałby antiocheńskie źródło powstania całego Dekretu Apostolskiego. Dlatego też niektóre kodeksy zachodnie poszerzają wersję Dz

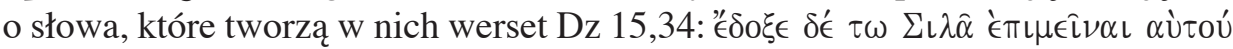
(ale Sylas postanowit tam pozostać) ${ }^{23}$. Widać zatem wyraźnie, że poprawność historyczna nie jest podstawowym celem napisania Dziejów Apostolskich przez św. Łukasza. ${ }^{24}$

\section{Podsumowanie}

Egzegeci zajmujący się problematyką Soboru Jerozolimskiego podają dwa sposoby rozwiązania sporu dotyczącego przyjęcia pogan na łono Kościoła: „model tzw. partnership według św. Pawła” i „model hierarchiczny według św. Łukasza". Potwierdzeniem tej teorii są dwa świadectwa NT: Ga 2,1-10 i Dz 15,1-35. Z punktu widzenia historycznego za plecami konfliktu stoi prawdopodobnie kolekta (Ga 2,10) na rzecz gminy jerozolimskiej ${ }^{25}$. W tle obrad pojawiło się pytanie: w jaki sposób Pawłowi udało się wywrzeć

${ }^{21}$ Por. H. Conzelmann, Die Apostelgeschichte, 89-91.

${ }^{22}$ Obszerniej na ten temat pisze A. Pitta w swoim komentarzu do Listu do Galatów. Rozważa on trzy propozycje. Fragment Ga 2,1-10 mógłby nawiązywać do trzech różnych tekstów z Dz, które relacjonują spotkania apostołów w Jerozolimie: Dz 11,27-30; 15,1-29; 18,22. Brak jakichkolwiek informacji na temat kolekty zebranej w Antiochii na rzecz ubogich w Jerozolimie (Dz 15) nie pozwala według A. Pitty połączyć dwóch tradycji literackich: Ga 2 i Dz 15. Por. A. Pitta, Lettera ai Gallati (SOCr 9), Bologna 1996, 125-126. Por. także E.E. Popkes, „Bevor einer von Jakobus kam...": Anmerkungen zur Textkritischen und Theologischgeschichtlichen Problematik von Gal 2,12, NovT (2004) 253; J.D.G. Dunn, The Incident at Antiochia, JSNT 18 (1983) 38.

${ }^{23}$ Por. B.M. Metzger, A Textual Commentary on the Greek New Testament, Stuttgart 19753, 439.

${ }^{24}$ Por. H. Conzelmann, Die Apostelgeschichte, 87; E. Haenchen, Die Apostelgeschichte, 469.

${ }^{25}$ Por. P.J. Achtemeier, An Elusive Unity: Paul, Acts, and the Early Church, 11. 
nacisk na wspólnotę jerozolimską, aby ta zaakceptowała jego argumenty bez stawiania zastrzeżeń dla całego dzieła misyjnego wśród pogan i jego zgodności z Prawem? Według relacji samego św. Pawła, rozwiązanie zostało odnalezione na podstawie dialogu braterskiego, w którym zarówno Piotr, jak i Paweł odnieśli się do osobistego doświadczenia podczas działalności misyjnej, tak pośród nawróconych spośród Żydów, jak i pogan. Rozwiązanie polegało na rozpoznaniu i uznaniu odmiennego chryzmatu misyjnego każdego z apostołów. Ostateczne rozwiązanie konfliktu, jakie prezentuje Łukasz jest pełne braterskiej harmonii i pokoju, a jego wypełnienie zostało złożone na ręce Pawła i Barnaby. Jednak mimo ostatecznego uznania ich doświadczenia i charyzmatu misyjnego wśród pogan, nie zostali oni dopuszczeni do gremium podejmującego końcowe postanowienia ${ }^{26}$.

Naturalnie, taka propozycja podsumowania Soboru Jerozolimskiego minimalizuje rolę Pawła i Barnaby podczas trwania obrad. Należy podkreślić również pierwsze różnice wyznaniowe, jakie wynikają z tekstu Dz 15,1-35, choć nie da się ich do końca zweryfikować. W każdym razie dla nawróconych pogan przewidziana jest nowa droga wiary, praktycznie całkowicie odrębna od zasad Starego Prawa, które w pierwszych latach gminy chrześcijańskiej w Jerozolimie ciągle odciskało swoje piętno. Kamieniem milowym na nowej drodze wiary jest przede wszystkim odejście od praktyki obrzezania, fundamentalnego znaku dla tych, którzy stają się wyznawcami Tory. Takie przedstawienie problemu włączenia pogan do grona wyznawców Chrystusa ukazuje mimo wszystko sympatię Łukasza dla pozycji św. Pawła. Inaczej nie da się zrozumieć, dlaczego ewangelista właśnie jego propozycję rozwiązania konfliktu wkłada również w usta św. Piotra i św. Jakuba, choć sam św. Paweł nie należy do gremium ustalającego zasady życia chrześcijańskiego dla pogan. Wydaje się, że św.Łukasz, opisując przebieg Soboru Jerozolimskiego z perspektywy „Pawłowej”, chciał ukazać zbliżenie całkowicie przeciwnych frakcji w pierwszych dniach istnienia Kościoła, aby dać czytelnikowi jednolity obraz dalszego przebiegu Historii Zbawienia.

Warto zauważyć, jeszcze jeden aspekt obrad Soboru Jerozolimskiego. Można go nazwać ,ekumenicznym”. W opisie Łukasza Dz 15,1-35 pierwotne Kościoły chrześcijańskie - Jerozolima i Antiochia - oscylują wokół dwóch biegunów: ,prawdy” i ,,jedności”. ${ }^{27}$ U św. Pawła, więc dla przedstawiciela Kościoła w Antiochii, emfaza położona jest na element prawdy. Paweł dla obrony prawdy Ewangelii gotowy jest na każdą formę konfliktu, czego przykładem jest List do

\footnotetext{
${ }^{26}$ Por. A. Suhl, Ein Konfliktlösungsmodell der Urkirche und seine Geschichte, BiKi 45 (1990) 80-86.

${ }^{27}$ Por. A. Strobel, Das Aposteldekret als Folge des antiochenischen Streites, w: Kontinuität und Einheit, Fs. F. Mussner, red. P.G. Müller - W. Stenger, Freiburg/B. 1981, 81-104.
} 
Galatów 2,1-10 (raport na temat konfliktu antiocheńskiego i ugody jerozolimskiej). Św. Łukasz ze swej strony kładzie nacisk na jedność. Obie te tendencje zostały przez niego spolaryzowane w perspektywie pokoju.

Czytając opis Soboru Jerozolimskiego (Dz 15,1-35), możemy stwierdzić, że św. Łukasz nie podziela nadmiernego optymizmu, jaki często spotykany jest w opisach i komentarzach do pierwszych wydarzeń w dziejach Kościoła. Obraz Kościoła, jaki kreśli św. Łukasz w opisie Soboru Jerozolimskiego, możemy nazwać realistycznym. Nie ma wątpliwości, że dla Łukasza żadna siła i moc tego świata nie może zahamować triumfalnego pochodu Słowa Bożego. $\mathrm{Z}$ drugiej strony, Łukasz nie przemilcza trudności zewnętrznych oraz kryzysów, jakie towarzyszyły wewnętrznemu wzrostowi pierwotnego Kościoła, które mogły przeszkodzić w ekspansji Słowa Bożego. Już faza przepowiadania Słowa w Jerozolimie skończyła się przelaniem krwi dla Chrystusa. Przed tymi wydarzeniami poszczególni apostołowie także doświadczyli prześladowań i upokorzeń. Jeden z nich, Jakub syn Zebedeusza został ścięty mieczem (Dz 12,2). Podobne doświadczenia zbierze również św. Paweł, poczynając od Pierwszej Podróży Misyjnej. Problemy zewnętrzne krzyżowały się z wewnętrznymi: kontrowersje związane $\mathrm{z}$ zaniedbywaniem wdów hellenistów (Dz 6,1-2) czy omawiany przez nas fragment mówiący o sporach przy towarzyszących nawróceniu pogan i włączeniu ich do wspólnoty Kościoła (Dz 15,1-35).

Tym samym św. Łukasz nie przemilcza zagrożeń dla Ewangelii, których źródłem są zarówno zewnętrzne siły i moce, jak i sama wspólnota wierzących. Ukazuje jednak również, w jaki sposób Słowo Boga rozszerza się pomimo przeszkód i trudności. Bez specjalnego wysiłku egzegetycznego możemy zauważyć to przesłanie św. Łukasza w perspektywie trynitarnej:

- od samego początku Kościół jest dziełem samego Boga. On to objawił swój plan budowy Kościoła na fundamencie Chrystusa złożony z Hebrajczyków i pogan. Plan ten ukazują dzieje Izraela, poczynając od patriarchów w mowie św. Szczepana (7,2-26); nastepnie w słowach Pisma: proroctwo Joela w mowie św. Piotra podczas Pięćdziesiątnicy $(2,17-21)$; w słowach apostoła Jakuba - cytat wyjęty z proroka Amosa w czasie obrad Soboru Jerozolimskiego (Dz 15,16-18); demonstruje to również idea wybrania, która pojawia się wiele razy w Księdze Dziejów Apostolskich (Dz 1,24; 9,15; 13,17; 15,7);

- Jezus Chrystus zostaje zabrany do Ojca podczas swego Wniebowstąpienia, ale pozostaje zawsze obecny we wspólnocie, z którą dzieli swoje przeznaczenie: korespondencja między prześladowaniem apostołów i św. Szczepana z jednej strony, a procesem i śmiercią Jezusa Chrystusa z drugiej. Chrystus, który zwołuje wspólnotę na modlitwę i który objawia się umierającemu Szczepanowi jako Pan 
historii (Dz 7,56), prowadzi i towarzyszy wspólnocie poprzez dzieje w swoim Słowie, które zostało jej dane i zadane.

- podobnie jak w Ewangelii św. Jana, po zmartwychwstaniu Chrystus jest obecny we wspólnocie przez Ducha Świętego. Tak jak Duch św. napełniał samego Chrystusa (tak obwieszcza św. Łukasz w swojej Ewangelii: Łk 10,21), tak determinuje on wszystkie fazy wzrostu młodego Kościoła. Już w dniu Pięćdziesiątnicy Duch św. zstąpił na apostołów w sposób dostrzegalny dla wszystkich narodów i przygotował Hebrajczyków pochodzących ze wszystkich części ówczesnego świata na przyjęcie wiary w Jezusa Chrystusa. W domu Korneliusza zostaje on zesłany w sposób widzialny i doświadczalny na rodzinę pogańską. Ten sam Duch pomaga również wspólnocie w Jerozolimie znaleźć rozwiązanie problemu dotyczącego przyjęcia pogan do wspólnoty Kościoła (Dz 15,28). Łukasz kładzie tym samym fundament pod wiarę i ufność sobie współczesnych czytelników i tych wszystkich, którzy przez wieki karmią się i żyją słowem Bożym w to, że Kościół jako dzieło samego Boga nigdy nie przestanie wzrastać w wierze i jedności. 


\section{Riassunto}

Il brano At 15,1-35 ci presenta un importante tappa dello sviluppo della chiesa primitiva. Per Luca nessun potere del mondo possa frenare il corteo trinfale della parola di Dio. Dall'altra parte Luca non passa di silenzio gli ostacoli da fuori e le crisi di crescimento da dentro che possono opporsi all'espansione della parola da parte della comunità. Gia la fase della predicazione della parola a Gerusalemme finiva con la versione di sangue. E già prima di questo avvenimento gli apostoli come individui o come gruppo avevano sperimentato la persecuzione o la castigazione. Da sua parte, uno di loro sarà uciso con la spada (At 12,2). Più tardi, Paolo farà le stesse esperienze sin dal suo primo viaggio misionario. Alle ostilità vissute da fuori vengono i conflitti all'interno della comunità: la controversia sull'assistenza alle vedove degli ellenisti in At 6 o quella sulle condizioni di ammissione dei gentili alla comunità in seguito al primo viaggio missionario di Paolo in At 15,1-35. Così, Luca non tacce sulle minaccie del vangelo da fuori o da dentro. Però mostra come la parola di Dio si espande irresistibilmente malgrado tutte le resistenze. 
